\title{
Joanna Grądziel-Wójcik
}

\section{"Trudne" wiersze. Wokół lingwistycznej poezji kobiet*}

\begin{abstract}
Grądziel-Wójcik Joanna, "Trudne” wiersze. Wokół lingwistycznej poezji kobiet [„Difficult” poems. On linguistic poetry by women]. „Przestrzenie Teorii” 30. Poznań 2018, Adam Mickiewicz University Press, pp. 187-204. ISSN 1644-6763. DOI 10.14746/pt.2018.30.9.

The article addresses the problem of absence of women's poetry in the linguistic current of 20th-century Polish poetry. It analyses its causes, amongst which the pivotal role is played by the stereotypical vision of women's poetry, deeply ingrained in general awareness. The vision in question does not admit "difficult" forms and thus places women's poetic work outside the avant-garde tendencies, linguistic experiment and metareflection. The authoress calls for inclusion of the omitted or forgotten poetesses who play with language in their poems and she articulates the need to redefine our understanding of linguistic poetry.
\end{abstract}

KEYWORDS: 20th-century Polish poetry, women's poetry, linguism, metapoeticity, Bogusława Latawiec, Marianna Bocian, Ewa Lipska

Nie istnieje lingwistyczna poezja kobiet, a dokładniej - opisujące praktykę pisarską XX wieku historycznoliterackie kompendia, decydujące w dużej mierze o współczesnym kształcie kanonu, nie uwzględniają tak sygnowanej twórczości poetek. Może jedynie z wyjątkiem Ewy Lipskiej, której wiersze umieszczane były zwykle w kontekście Nowej Fali i wiązane z lingwistyczna aktywnościa pokolenia. Podręczniki i antologie przez lata utrwalały przekonanie, że ta uznawana za „najbardziej wyrafinowana i spekulatywna” aktywność poetycka, która „[z]a dziadków miała Peipera i Przybosia, za ojców Białoszewskiego i Karpowicza"1, stanowi domenę jednej płci. Do autorów wymienionych pod koniec lat siedemdziesiątych przez Jana Błońskiego dołączyli najczęściej przywoływani: Zbigniew Bieńkowski, Witold Wirpsza, Edward Balcerzan, Stanisław Barańczak, Ryszard Krynicki. Ich twórczość stanowiła egzemplifikację dla - poprzedzonych prelingwizmem pierwszej awangardy ${ }^{2}-$ dwóch odsłon nurtu w literaturze powojennej: poezji założycielskiej przełomu lat pięćdziesiątych i sześćdziesiątych XX wieku

* Artykuł został napisany w ramach badań finansowanych ze środków Narodowego Centrum Nauki (projekt badawczy nr 2015/17/B/HS2/01245).

${ }^{1}$ J. Błoński, Diagnozy i prognozy, [w:] tegoż, Odmarsz, Kraków 1978, s. 168-186.

${ }^{2} \mathrm{O}$ zapowiadającej praktyki poetyckie lingwistów poezji futurystycznej i słowiarskiej zob. B. Sienkiewicz, (Neo)lingwizm - dokończony projekt awangardy, [w:] tejże, Poznawanie $i$ nazywanie. Refleksja cywilizacyjna $i$ epistemologiczna $w$ polskiej poezji modernistycznej, Kraków 2007, s. 582; A. Kluba, Poetyki lingwistyczne, „Przestrzenie Teorii” 2005, nr 5, s. 94; 
oraz twórczości pokolenia Nowej Fali na początku lat siedemdziesiątych. Osobowy skład neolingwizmu z przełomu stuleci jako „trzeciej realizacji lingwizmu poetyckiego w powojennej poezji polskiej”3 znacząco się już jednak różnicuje, gdy do głosu dochodzi pokolenie aktywnych programowo poetek (Joanna Mueller, Maria Cyranowicz, Katarzyna Hagmajer, Aneta Kamińska, Joanna Roszak), a przy okazji reaktywacji zainteresowań językiem lingwistyczną afiliację spośród autorek dwudziestowiecznych zyskuje (niejako wstecznie) Krystyna Miłobędzka. Jej poezja ponad trzydzieści lat po debiutanckich Anaglifach i proklamowaniu lingwizmu w literaturze staje się jego sztandarowym przykładem w wydaniu kobiecym ${ }^{4}$, otwierając i, niestety, zwykle zamykając listę obecności kobiet w poezji.

Gestem założycielskim lingwizmu w badaniach literackich był tekst Janusza Sławińskiego Próba porzqdkowania doświadczeñ ${ }^{5}$ z 1964 roku, który włączył termin w obieg naukowy i krytycznoliteracki, a sama nazwa, choć określana bywała jako pleonastyczna ${ }^{6}$ i prowokowała do dyskusji, przyjęła się i spopularyzowała, stając się kategorią odnoszoną i reinterpretowaną przez kolejne pokolenia twórców, wśród których znajdowali się niemal wyłącznie mężczyźni. O ile bowiem Barańczak i Krynicki wykorzystywali w swoich projektach pojęcie poezji lingwistycznej, przeformułowując je na własny, programowy użytek ${ }^{7}$, o tyle poetki tego nie czyniły albo też nie udało im się utrwalić swych wystapień w pamięci historycznoliterackiej. Powtórzyć wypada w tym miejscu pytanie Karola Maliszewskiego, który zastanawia się nad nieobecnością kobiet w historii literatury, wyznaczonej rytmem przełomów i pokoleń: „czy nikła liczba nazwisk kobiecych w histo-

T. Cieślak-Sokołowski, Moment lingwistyczny. O wczesnym pisarstwie Ryszarda Krynickiego $i$ Stanistawa Barańczaka, Kraków 2011, s. 20.

${ }^{3}$ T. Cieślak-Sokołowski, Moment lingwistyczny..., s. 18.

${ }^{4}$ Zob. np. K. Hoffmann, M. Jaworski: Poezja polska po roku 1989, [w:] Przechadzki po polskiej literaturze najnowszej, red. J. Grądziel-Wójcik, J. Jastrzębska, Z. Kopeć, Poznań 2014, s. 35; Powiedzieć to inaczej. Polska liryka nowoczesna. Antologia. Autorzy wyboru J. Borowczyk, M. Larek, Poznań 2011, s. 6.

${ }^{5}$ J. Sławiński, Próba porzqdkowania doświadczeń, [w:] tegoż, Prace wybrane, t. V: Przypadki poezji, red. W. Bolecki, Kraków 2001. Tomasz Cieślak-Sokołowski próbuje osłabić tezę o kreacji tego terminu przez Sławińskiego, przywołując m.in. teksty Jerzego Kwiatkowskiego, Jana Prokopa czy Jana Bieńkowskiego, ale przyznaje też, że to publikacja Próby porzqdkowania doświadczeń w 10. numerze „Odry” z 1964 roku stanowiła „moment ustanowienia dyskursu poezji lingwistycznej”; zob. T. Cieślak-Sokołowski, Moment lingwistyczny..., s. 117 (cytat), s. 122-123.

${ }^{6}$ Zob. S. Barańczak, Nieufni i zadufani. Romantyzm i klasycyzm w młodej poezji lat 60., Wrocław 1971, s. 30.

${ }^{7}$ Zob. tamże oraz R. Krynicki, Czy istnieje już poezja lingwistyczna?, „Poezja” 1971, nr 12. O „momencie lingwistycznym” we wczesnym pisarstwie obu poetów traktuje wspomniana już książka T. Cieślaka-Sokołowskiego, Moment lingwistyczny... 
rycznoliterackich statystykach to fakt, który wiąże się z tym, że procent aktywnych poetek (w stosunku do poetów) był rzeczywiście wielokrotnie mniejszy, czy też podsuwany nam obraz jest zafałszowany, a wyciagane zeń wnioski zmanipulowane?"'.

W ukształtowanym przez podręczniki, antologie i inne kompendia obrazie historii polskiej poezji nie ma mowy o zaangażowaniu kobiet $\mathrm{w}$ dwie pierwsze fazy lingwizmu - nawet jeśli zostały one rozpoznane przez krytykę jako realizujące założenia nurtu, nie pozostał po nich znaczący ślad w historii literatury, który utrwaliłby ich pozycję w powszechnej świadomości. Późniejsza refleksja badawcza stwierdzała otwartość lingwizmu traktowanego jako niemożliwy do spełnienia projekt epistemologiczny ${ }^{9}$ i proklamowała jego historycznoliterackie niedomknięcie - podkreślając przy tym konsekwencje definicyjnych trudności oraz „brak możliwości ukonstytuowania stałego obrazu przedmiotu opisu" ${ }^{10}$, nie upomniała się jednak przy okazji o pomijane lub marginalizowane propozycje poetyckie poetek.

Owo wypieranie kobiet poza obręb refleksji lingwistycznej zaobserwować można na przykładzie poezji Bogusławy Latawiec, której debiut przypadł na połowę lat sześćdziesiątych i podobnie jak następny tomik ${ }^{11}$ został zgodnie włączony przez krytykę w tradycję awangardową ze szczególnym wskazaniem na lingwistyczne filiacje: nawiązywał „do jednej z najnowszych konwencji artystycznego eksperymentu - «słowiarstwa»" ${ }^{2} \mathrm{i}$ wpisywał się $\mathrm{w}$,aurę eksperymentów lat sześćdziesiątych" ${ }^{13}$, bohaterami poetyckiej refleksji czyniąc język - „myśl, słowo, zdanie, sens, linię foniczną czy też «konstrukcję» z liter” ${ }^{14}$. Stanisław Balbus pisał o „komplikującym sprawę” słowie, które czyni tę poezję „,aktywna, kreujaca; słowie, które stwarza świat”" ${ }^{15}$, Karpowicz zaś zauważał bliską Przybosiowej „samoświadomość «roboty słownej»” oraz towarzysząca jej „wielką świadomość teoretyczną procesu "zapisu», «słowiarstwa»"'16. Tę lingwistyczną wrażliwość diagnozowano nie tylko we wczesnych

${ }^{8}$ K. Maliszewski, Przełomy i pokolenia bez kobiet?, [w:] Formy (nie)obecności. Szkice o wspótczesnej poezji kobiet, red. J. Grądziel-Wójcik, E. Sołtys-Lewandowska, A. Kwiatkowska, Kraków 2018, s. 39.

${ }^{9}$ A. Skrendo, Poezja lingwistyczna jako projekt epistemologiczny. Zerwanie, ustanowienie, zawieszenie, „Poznańskie Studia Polonistyczne. Seria Literacka” 2006, z. XIII. Kamp, lingwizm: niedokończone projekty nowoczesności, s. 23.

${ }^{10}$ T. Cieślak-Sokołowski, Moment lingwistyczny..., s. 16.

${ }^{11}$ Bogusława Latawiec (ur. 1939) debiutowała w 1965 r. tomem Otwieraja się rzeki, w 1970 r. ukazało się Całe drzewo zdania, a w 1975 - Przestrzenie.

12 J. Witan, Niepokój zamkniętych stów, „Odra” 1966, nr 9.

${ }^{13}$ R. Matuszewski, Woda, palce, litery, „Życie Literackie” 1965, nr 31.

${ }^{14}$ W. Grajewski, W środku myśli, „Poezja” 1970, nr 12.

${ }^{15}$ S. Balbus, Z dziennika lektur poetyckich, „Życie Literackie” 1971, nr 1.

${ }_{16}$ T. Karpowicz, Dziennik Zwiazkowy (Polish Daily News), Chicago, 15-17 XI 1991. 
wierszach Latawiec, wpisujących się w nurt poszukiwań językowych przełomu lat sześćdziesiątych i siedemdziesiątych - „to poezja w pewnym sensie trudna, skoro jej opanowanie wymaga odtworzenia reguł stwarzanych przez nią sama" ${ }^{17}$ - lecz także w tej późniejszej, kontynuującej słowiarskie tendencje: o Odkrytkach z 2007 roku Jacek Klejnocki pisał: „Cały tomik zawiera wiersze skondensowane w znaczeniach. To elitarna, trudna liryka osobista, mówiąca o kwestiach zwykłych, [...] filozofująca i estetyzująca jednocześnie” ${ }^{18}$. W twórczości autorki Powidoku podkreślano „lekką "lingwistyczna»" komponentę, w szczególności w pierwszym okresie rozwoju jej pisarstwa"19, przypominano, że „to oczywiście także język w języku”"20, nazywano poetkę " "przemyślną lingwistką", lingwistką liryczną" ${ }^{21}$ spod znaku Karpowicza. Krytycy z jednej strony zgodnie włączali jej wiersze w krag poetyckich eksperymentów, widząc w nich efekt szczególnej pracy nad językiem, z drugiej zaś podnosili zastrzeżenia, które przeszkadzały jednoznacznej ich klasyfikacji, czego wymowny przykład stanowi wypowiedź Wiktora Woroszylskiego:

Jeżeli w ogóle potrzebne jest jakieś przyporządkowanie, to autorkę nigdy całości należałoby umieścić w wybitnie „męskim” nurcie „,awangardowym” i „lingwistycznym”, wiązanym z nazwiskami Przybosia i Karpowicza. Ale i to nie byłoby do końca ścisłe, bo przy całej dziedziczonej, być może, po wymienionych poetach, skłonności do lakonizmu, niedopowiedzenia, zaskakującego konstruowania skojarzeń, porównań, składni, Bogusława Latawiec nie przejęła oschłości mistrzów, „ociepliła”, userdeczniła obrany wzorzec, przedkładając w sumie odmienny i nader interesujący wariant „nowoczesnej” liryki ${ }^{22}$.

Z ujęciem tym polemizowała Joanna Dembińska-Pawelec, postrzegając twórczość Latawiec jako „bardzo kobieca, prezentującą sfeminizowany sposób odczuwania, wyrażania, wrażliwości oraz sfery imaginacji. Autorka korzysta z wypracowanych technik poetyki awangardowej i chwytów lingwistycznych, ale czyni to na sposób wyraźnie kobiecy”"23. Przypadek tej poezji uwidacznia tym samym problem, który komplikuje obraz twórczości

${ }^{17}$ W. Grajewski, dz. cyt.. Wszystkie wyróżnienia w cytatach, jeśli nie zaznaczono inaczej,- JGW.

${ }^{18}$ J. Klejnocki, Tajemnica, „Polityka”, 1 III 2008.

${ }^{19}$ L. Szaruga, Rozptywajace się zdanie, „Nowe Książki” 1995, nr 10.

${ }^{20}$ J. Drzewucki, Język w języku, „Rzeczpospolita” 31.07.1999.

${ }^{21}$ K. Lisowski, „O czasie po czasie”, „Nowe Książki” 2015, nr 5, <http://www.wforma. eu/-o-czasie-po-czasie-nowe-ksiazki-12-2015.html> [dostęp: 6.08.2018].

${ }^{22}$ W. Woroszylski, Dwugłos o „Nigdy całości”, „Arkusz” 1995, nr 4, s. 9.

${ }^{23}$ J. Dembińska-Pawelec, Arachne z ulotna nicia. Sygnatura kobieca w późnej poezji Bogustawy Latawiec, „Poznańskie Studia Polonistyczne. Seria Literacka” 2018, nr 32, s. 269. Sąd Woroszylskiego doczekał się także innych komentarzy, zob. P. Łuszczykiewicz, Wiersze, sny, obrazy Bogustawy Latawiec, [w:] J. Grądziel-Wójcik, P. Łuszczykiewicz, Bogustawa Latawiec. Portret podwojony, Kraków 2016, s. 27.; J. Grądziel-Wójcik, Przymiarki do istnienia. Watki i tematy poezji kobiet XX $i$ XXI wieku, Poznań 2016, s. 153-154. 
uznawanej za lingwistyczną i nie pozwala dopasować się tekstom kobiet do przyjętego, męskocentrycznego wzorca - to właśnie ich „kobiecy” wymiar, silnie osobisty i liryczny, nie do pogodzenia, jak mogłoby się wydawać, z językowym utrudnieniem formy. Stanowi on podstawowy argument przemawiający za usytuowaniem wierszy Latawiec poza głównymi nurtami: „Zapewne ta właśnie «trudność», czy może inaczej: brak łatwego lekturowego dostępu w dużej mierze decyduje o jej osobnym miejscu na mapie polskiej poezji” - pisał Tomasz Cieślak-Sokołowski, dodając: „Wiersze autorki Odkrytek nie mieszczą się w żadnej z wpływowych, dyskutowanych z zapałem opozycji: ani klasycystyczne, ani ostentacyjnie awangardowe, ani poddane bez reszty wyzwalaniu wyobraźni, ani owładnięte pasją lingwistycznych przekształceń” ${ }^{4}$. Owa „trudność”, wielokrotnie podkreślana przez krytyków dystansujących się wobec „lingwistycznych” dokonań pisarki (znamienny cudzysłów w wypowiedzi Woroszylskiego), staje się sygnaturą tej poezji, nie pozwalając na włączenie jej w tradycyjne uporządkowania i jednocześnie spychając na historycznoliteracki boczny tor.

Pytanie o (nie)obecność poetek w nurcie lingwistycznym i jego historycznoliteracką redefinicję wiązać należy zatem z silnie utrwaloną wizją liryki kobiecej, dowartościowującej w powszechnym odbiorze kategorie bezpośredniości, uczuciowości i stylistycznej rozlewności, nadmiernej metaforyczności, afirmatywności czy aintelektualizmu ${ }^{25}$. Wciąż jeszcze, przyznaje z perspektywy praktykujacej lingwistki Maria Cyranowicz, „za kobiece według wzorca kultury uważa się epatowanie swoją emocyjnościa, naiwność, delikatność, pisanie o miłości z unikaniem oczywistej fizjologii, traktowanie mężczyzn jako wiecznych adoratorów” ${ }^{26}$. Z wyrastającym z tego kulturowego rozumienia kobiecości modelem poezji kłócą się myślące, zapośredniczające emocje w języku, „trudne” wiersze kobiet. Sprzeczność tę podnosi także Anna Legeżyńska, dla której twórczość Krystyny Miłobędzkiej „na pewno ma charakter elitarny, lecz trudno orzec, w jakim stopniu typowy dla paradygmatu liryki kobiecej”, zaś sama poetka należy do nielicznych autorek podejmujących „ponowoczesną refleksję lingwistyczna” ${ }^{27}$. Tymczasem z trudności można uczynić wartość, o czym świadczy propozycja odczytania Piotra Bogaleckiego, dla którego „niezrozumiałość” staje się kategoria interpretacyjną wierszy Miłobędzkiej, sprawiających „wrażenie trudnych,

${ }^{24}$ T. Cieślak-Sokołowski, Przy słowie, „Dekada Literacka” 2008, nr II-III.

${ }^{25}$ Zob. E. Kraskowska, Piórem niewieścim. Z problemów prozy kobiecej dwudziestolecia międzywojennego, Poznań 1999, s. 19.

${ }^{26}$ M. Cyranowicz, [w:] Gada!Zabić. Pa]n[tologia neolingwizmu, nawigacja: M. Cyranowicz, P. Kozioł, Warszawa 2005, s. 245.

${ }^{27}$ A. Legeżyńska, Od kochanki do psalmistki... Sylwetki, tematy $i$ konwencje liryki kobiecej, Poznań 2009, s. 336, 337. Należałoby tylko dodać - wśród autorek starszego pokolenia, przypominając o aktywnych w tym zakresie neolingwistkach. 
niezrozumiałych, a często nawet «nieczytelnych»" ${ }^{28}$. Autorka Imiesłowów jest tu jednak znamiennym wyjątkiem, z reguły bowiem „trudność” wydaje się mniej akceptowalna, jeśli dotyczy poezji kobiet, wobec której, w potocznym zwłaszcza odbiorze, wciąż pokutuje myślenie spychające w koleiny formy „łatwej i przyjemnej”, zaś to, co „elitarne” i „wyrafinowane” - komplikacje języka, skłonność do eksperymentu, zabiegi autotematyczne - nie przystaje do skonwencjonalizowanego, masowego stylu odbioru „liryki kobiecej”. Sensowność jej wyodrębniania kwestionują przede wszystkim same poetki, podkreślając, że „nie da się sformułować wyznaczników, według których wiersze odpowiadałyby tej kategorii”, nie każda też poezja kobiet chce się odróżniać od tej pisanej przez mężczyzn ${ }^{29}$. Według Justyny Radczyńskiej:

Oczywiście funkcjonuje subkategoria „poezja kobieca” - odwołujacca się do stereotypów kobiecości, a więc - uczuciowa, sentymentalna, egzaltowana, a co gorsza pretensjonalna, landrynkowata, sztambuchowata, ekshibicjonistyczna, czyli ogólnie „słaba”. Tak kategoria ma charakter wykluczający, dlatego nie można jej stosować. [...] akceptuja oni tylko takie komunikaty kobiet, które pasuja do archaicznych i stereotypowych wyobrażeń kobiecości. Są to komunikaty do bólu przewidywalne, często przypisane do tzw. ról kobiecych, typowe dla kobiet „obłaskawionych”, trzymających się politycznie i obyczajowo w ryzach poprawności ${ }^{30}$.

Można by dodać - trzymające się także w ryzach językowej poprawności, bez utrudniających odbiór lingwistycznych ekscesów. Jak konstatuje Legeżyńska w zakończeniu swojej książki poświęconej poetkom przyjmującym role symptomatycznie rozpięte między „kochanką” a „psalmistką”:

Na ogół [...] w liryce kobiecej kwestia języka jako komunikacyjnego medium nie wybija się na plan pierwszy, nie dominuje tak totalnie. Czy wynika stąd wniosek, że poetki ufają mowie jako narzędziu komunikacji, a co za tym idzie, nie poddają się powszechnej w XX wieku presji „niewyrażalności”? [...] Kto wie, czy w poetyce odbioru liryki kobiecej nie mieści się [...] - ustalona przez tradycję - norma komunikacyjna, która nakazuje „zrozumiałość” ekspresji? ${ }^{31}$.

Postawione tu pytanie nie musi być retoryczne. Chodzi o to, by przekroczyć kulturowe stereotypy i zneutralizować oksymoroniczny wymiar „trudnej” poezji kobiet, która zresztą skutecznie wywalcza sobie w ostatnich latach prawo do myślenia i samostanowienia - również za pomocą refleksji metapoetyckiej i formy utrudnionej, by przywołać projekty Joanny Mueller, Justyny Bargiel-

${ }^{28}$ P. Bogalecki, Niedorozmowy. Kategoria niezrozumiałości w poezji Krystyny Miłobędzkiej, Warszawa 2011, s. 29.

${ }^{29}$ Zob. M. Cyranowicz, J. Mueller, J. Radczyńska, Solistki bez chóru. Pożyteczne refleksje, [w:] Solistki. Antologia poezji kobiet (1989-2009), red. M. Cyranowicz, J. Mueller, J. Radczyńska, rysunki P. Dwurnik, M. Ignerska, Warszawa 2009, s. 222.

${ }_{30}$ Tamże.

${ }^{31}$ A. Legeżyńska, dz. cyt., s. 337-338. 
skiej, Anety Kamińskiej, Joanny Roszak, Marii Cyranowicz czy przygodnie ${ }^{32}$ korzystającej z lingwistycznego potencjału Julii Fiedorczuk ${ }^{33}$. Choć w ostatnich dwóch dekadach zaszły wyraźne zmiany w recepcji twórczości kobiet dzięki działalności programowej, manifestowej i krytycznoliterackiej samych poetek, wciąż wiele jest jeszcze do zrobienia - opisania - zwłaszcza jeśli chodzi o przywrócenie pamięci historycznoliterackiej autorek piszących w czasach PRL-u ${ }^{34}$.

Podobny przykład marginalizacji przynosi przynależąca głównie do tego okresu twórczość Marianny Bocian, autorki bliskiej rocznikowo i debiutujacej w podobnym czasie co Bogusława Latawiec, ale łączonej już z pokoleniem Nowej Fali ${ }^{35}$. Mimo iż sama autorka po latach polemizowała z takim zaszeregowaniem ${ }^{36}$, krytyka lat siedemdziesiątych wiazała jej konkretystyczna poezję z lingwizmem, podkreślając autoteliczność tekstów i akcentując ich

${ }^{32}$ Jeśli uznać lingwizm za cechę stopniowalna, niekoniecznie determinowaną programem poetyckim i funkcjonalną niekiedy na terenie jednego tekstu, to $\mathrm{w}$ tak szerokim rozumieniu bez problemu mieszczą się teksty poetek, którym bliska jest jej lingwistyczność przygodna - nazywana przez Pawelca dyskretną lub rozproszona, a przez Klubę - okazyjną (D. Pawelec, Między dyskrecja a dyspersja. Oblicza końca poezji lingwistycznej, „Poznańskie Studia Polonistyczne. Seria Literacka” 2006, z. XIII. Kamp, lingwizm: niedokończone projekty nowoczesności, s. 10; A. Kluba, dz. cyt., s. 94). Takie doraźne, semantycznie nośne zabiegi „momenty lingwistyczne” - można zaobserwować w wierszach bardzo różnych od siebie poetek, niedających się włączyć „systemowo” do nurtu lingwistycznego, np. u Ludmiły Marjańskiej, Wisławy Szymborskiej, Uty Przyboś, a także Agnieszki Kuciak i Julii Fiedorczuk.

${ }^{33}$ Poetka, będąc spadkobierczynią awangardy, postuluje trudność poezji i zgoła lingwistyczne testowanie granic języka w celu wzmocnienia funkcji myślenia wierszem. W interpretacji poezji Fiedorczuk przydatne może stać się także pojęcie biolingwizmu, łączące lingwistyczną i autotematyczną refleksję nad słowem poetyckim z organicznościa języka poetyckiego, biologicznościa jego metaforyki i obrazowania. Więcej na ten temat zob. J. Gradziel-Wójcik, Konstelacje neoawangardy w poezji kobiet na przykładzie twórczości Julii Fiedorczuk, „Zagadnienia Rodzajów Literackich” 2018, z. 2, s. 124-130.

${ }^{34}$ „Pisarstwo kobiet z lat 1945-1989 [...] niemal nie zasiliło kanonu, egzystuje w mgławicowej niedookreśloności”, jak pisała Inga Iwasiów; I. Iwasiów, A. Galant, Wstęp [w:] Pisarstwo kobiet pomiędzy dwoma dwudziestoleciami, Kraków 2011, s. 6. Np. w pracy zbiorowej $P R L$ - świat (nie)przedstawiony (red. A. Czyżak, J. Galant, M. Jaworski, Poznań 2010) na osobne miejsce spośród poetek zasłużyła jedynie Krystyna Miłobędzka (obok omówienia kobiecej prozy wspomnieniowej). Mimo to luka w opisie twórczości kobiet tego okresu stopniowo się wypełnia, m.in. dzięki takim właśnie publikacjom jak Pisarstwo kobiet pomiędzy dwoma dwudziestoleciami (choć udział poetek jest w nim niewielki) czy tematycznemu numerowi „Poznańskich Studiów Polonistycznych” - (Nie)opisane. Poetki polskie XX i XXI wieku (część I) („Poznańskie Studia Polonistyczne. Seria Literacka” 2018, nr 32 (52)).

${ }^{35}$ Marianna Bocian (1942-2003) debiutowała tomem Poszukiwanie przyczyny pod pseudonimem Jan Bełczęcki w 1966 roku, kolejne tomy w latach siedemdziesiątych, począwszy od Wieży Babel pospolitej (1972), wychodziły już pod jej własnym nazwiskiem.

${ }^{36}$ W latach 90. Bocian pisała: „Jeśli chodzi o Karpowicza - u niego wiele się nauczyłam z tego, czym jest kompozycja utworu i tomu poetyckiego. Karpowicz uzmysławiał, że poeta jest tylko ten, kto tworzy swoją własną poetykę. Ja nie byłam od początku poetką lingwistyczną (co to znaczy!). Natomiast miałam kłopoty z kompozycja. To fakt" (fragmenty listu do Wioletty 
awangardowe korzenie ${ }^{37}$. Również Małgorzata Dawidek-Gryglicka w swojej monografii tekstu wizualnego, dostrzegając źródła polskiego konkretyzmu w wierszach lingwistycznych Mirona Białoszewskiego i Mariana Grześczaka, wśród najważniejszych twórców nurtu wymienia obok Stanisława Dróżdża właśnie Mariannę Bocian, poświęcając jej osobny rozdział ${ }^{38}$.

Warto przypomnieć, że poetka była także autorką programowych i manifestowych wypowiedzi ${ }^{39}$, w których prezentowała - równoległa obok propozycji nowofalowej - drogę dochodzenia konkretystów do „wolności aktu poetyckiego", sprzeciwiając się dehumanizacji sztuki i manipulacji słowem ${ }^{40}$. A jednak twórczość Bocian, naznaczona nieufnością i podejrzliwością wobec języka propagandy, stanowiąca reakcję na „rzeczywistość kryzysu mowy”11 i zabiegająca o zachowanie jej wymiaru etycznego, rzadko bywa rozpatrywana w kontekście Nowej Fali równolegle z poezją głównych jej protagonistów. Eksperymenty autorki Narastania i jej lingwistyczne inspiracje nie pozostały niezauważone, trafiając na marginesy podręczników ${ }^{42}$, lecz nie udało im się wydobyć z niszy drugorzędności - okazały się „,wykwitem” Nowej Fali ${ }^{43}$, przekraczając ramy wyznaczone przez mainstreamowy nurt pokolenia.

Teksty Bocian, zbaczające z utartych szlaków poezji nowofalowej, sa bowiem (podobnie zreszta jak wiersze Latawiec, choć realizowane w innym poetyckim idiolekcie) w różnym stopniu lingwistyczne i neoawangardowe ${ }^{44}$.

Rybki); cyt. za: M. Dawidek-Gryglicka, Ścieżki języka wedtug Marianny Bocian, [w:] Historia tekstu wizualnego. Polska po 1967 roku, Kraków-Wrocław 2012, s. 224.

${ }^{37}$ Zob. J. Wesołowski, Konkretna poezja. Materiały do „Stownika rodzajów literackich”, „Zagadnienia Rodzajów Literackich” 1974, R. XVII, z. 2; A. Zawada, Od krzyku do milczenia, „Poezja” 1974, nr 1 (98).

${ }^{38}$ M. Dawidek-Gryglicka, dz. cyt.

${ }^{39} \mathrm{~W}$ jednej z nich znajdujemy charakterystyczną dla dykcji awangardowej, wsparta strukturalistycznym myśleniem deklarację: „Nie jest w sztuce istotne CO przedstawiamy, ważne jest JAK"; M. Bocian, Bez manifestu, [w:] Konkrety [katalog wystawy Marianny Bocian], Wrocław, 1971, s. 8.

${ }^{40}$ M. Bocian, Przestrzeń w poezji konkretnej. Ogólnopolskie sympozjum nt. poezji konkretnej, Bydgoszcz 20-21 października 1979 r., Bydgoszcz 1979, s. 5-6.

${ }^{41}$ T. Nyczek, Wieża Babel, albo w pętli słowa, „Konfrontacje Literackie” 1972 [suplement], s. 57.

${ }^{42}$ Stanisław Burkot sytuuje Bocian poza wystapieniami grupowymi Nowej Fali, „[n]a obrzeżach głównych sporów generacyjnych”, przywołując jej tomiki z lat siedemdziesiątych: Wieża Babel pospolita, Narastanie i Proste nieskończone; zob. S. Burkot, Literatura polska w latach 1939-1989, Warszawa 1993, s. 214. Poetka wspomniana została także, obok Ewy Lipskiej, w portrecie zbiorowym pokolenia w podręczniku A. Legeżyńskiej, P. Śliwińskiego, Poezja polska po 1968 roku, Warszawa 2000, s. 23.

${ }^{43}$ „Konkretyzm również często definiowano jako wykwit po przełomie nowofalowym”, jak pisze Dawidek-Gryglicka, dz. cyt., s. 96.

${ }^{44} \mathrm{~W}$ znaczeniu zaproponowanym przez autorów monografii Nauka chodzenia. Teksty programowe późnej awangardy, która pokazuje świadomość późnonowoczesna w metapoetyc- 
Trafnie określił problem Tadeusz Nyczek pod koniec lat siedemdziesiątych: „jest to jedna jeszcze współczesna poezja, w której problem języka podnosi się do rangi dramatu człowieka”, jednocześnie „oscyl[ując] między niewiara i wiarą w słowo, przy czym bardziej deklaratywna wydaje się ta pierwsza, zaś autentyczniejsza ta druga" ${ }^{45}$. Także dla Anny Legeżyńskiej, interpretującej twórczość Bocian trzy dekady później, stanowi ona wariant poezji kobiecej, który „tematyzuje kryzys mowy” jako „więzienia rzeczy” i zarazem sytuuje „Słowo wobec Słowa”, tęskniąc za „mową przednowoczesna”, opartą na religijnych podstawach ${ }^{46}$. Obok kłopotu z kobiecością i lirycznością pojawia się tu zatem jeszcze jeden kłopot, tym razem związany z „nowoczesnością" poezji kobiet. Owa „nienowoczesność” wierszy autorki Odczucia i realności, wyrażająca się odmową uczestnictwa w „poststrukturalistycznym «liftingu»" ${ }^{\prime \prime}$ i rezygnacją z perspektywy postsekularnej, uniemożliwiła zapewne ich włączenie - mimo lingwistycznych praktyk, podejrzliwości wobec języka i teologiczno-religijnych poszukiwań - w zaproponowany przez Bogaleckiego koncept teolingwizmu.

„Trudny” temat lingwistycznej poezji kobiet naprowadza tym samym na szerszy problem jej awangardowej przynależności, której naturalną konsekwencja jest nakierowanie na język, a także ścisłe powiązanie z metapoetyckościa, autotematyzmem, autorefleksją poetycką ${ }^{48}$. Te dwie współpracujące ze sobą perspektywy, nie tylko, rzecz jasna, w twórczości pisanej przez kobiety, właśnie na jej terenie są relatywnie słabiej postrzegane.

kich wypowiedziach przedstawicieli polskiej neoawangardy lat sześćdziesiątych i siedemdziesiątych XX wieku. Wśród wskazywanych cech literatury neoawangardowej po 1956 roku znalazły się: programowość i metakrytyczny charakter wypowiedzi poetyckich, samoświadomość i eksperymentalność formy, postulat zaangażowania literatury, silnie związanej z aktualna rzeczywistością społeczna, jej ścisły związek z miastem oraz nakierowanie na problematykę cielesności i codzienności. Zob. J. Orska, Nauka chodzenia. O programowych wypowiedziach późnej awangardy, [w:] Nauka chodzenia, t. 1. Teksty programowe późnej awangardy, red. W. Browarny, P. Mackiewicz, J. Orska, Kraków 2018, s. 7-20.

${ }^{45}$ T. Nyczek, dz. cyt.

${ }^{46}$ Zob. A. Legeżyńska, dz. cyt., s. 315, 317.

${ }^{47}$ P. Bogalecki, Szczęśliwe winy teolingwizmu. Polska poezja po roku 1968 w perspektywie postsekularnej, Kraków 2016, s. 29-30. Autor analizuje w perspektywie teolingwizmu twórczość trzech poetek: Krystyny Miłobędzkiej, Joanny Mueller i Justyny Bargielskiej.

${ }^{48} \mathrm{~W}$ historycznoliterackiej refleksji dominuje tendencja do sytuowania kobiet poza literaturą nowoczesna, w szczególności tą o awangardowych koneksjach, zaś lista poetek kojarzonych z nurtem awangardowym w podręcznikach i antologiach jest bardzo krótka (najczęściej stanowia ją Ewa Lipska i Krystyna Miłobędzka). Zob. np. P. Śliwiński, Przygody z wolnościq. Uwagi o poezji wspótczesnej, Kraków 2002, s. 84; G. Ritz, Kanon i historia literatury. Widziane z zewnatrz, [w:] Kanon i obrzeża, red. I. Iwasiów, T. Czerska, Kraków 2005, s. 38; M. Świerkosz, Historia literatury kobiet - niedokończony projekt, „Wielogłos” 2011, nr 2, s. 67; L. Hull, Obok kanonu. Poezja kobiet w przestrzeni literatury po 1945 roku, „Prace Literaturoznawcze" 2013, nr 1, s. 97-98. 
Tym ciekawsze wydają się tu przykłady nakładania się na siebie tych dwóch obszarów, gdy „moment lingwistyczny” implikuje „moment metapoetycki”, a poezja - skoncentrowana na swym własnym medium - owa świadomość narzędzia dodatkowo ujawnia ${ }^{49}$. W wypadku poetek wiąże się to często, jak zaznacza Cyranowicz, z „walką o to, by czytelnicy zwrócili uwagę na tekst sam w sobie, a nie tylko na zawarte w nim rekwizyty i tematy"50, dlatego dzięki metarefleksyjnym ujawnieniom starają się one przeciwdziałać traktowaniu ich tekstów w kategoriach formalnej przezroczystości, bezpośredniości i zrozumiałości. Poetyckie metawypowiedzi, wsparte lingwizującymi chwytami, stanowią tym samym rodzaj poetyckiej samoobrony przez kulturowym stereotypem, a zarazem atrybut tej poezji o (neo)awangardowych koneksjach, eksperymentującej, zintelektualizowanej - „myślącej” i zarazem owo myślenie tematyzującej, czego świadectwem chociażby wiersze Marianny Bocian, Bogusławy Latawiec czy Krystyny Miłobędzkiej ${ }^{51}$. Dostrzeżenie metapoetyckich i lingwistycznych mariaży w poezji kobiet zmusza jednocześnie do przewartościowania ujęć lokujących poetki poza lub na obrzeżach modernizmu - rzadko się o nich wspomina w tym kontekście właśnie ze względu na wyznaczony przez tradycyjne ramy lektury wspomniany konglomerat cech „łatwej” poezji, stanowiący odpowiedź na diagnozowany w niej „radykalizm retrospektywny” ${ }^{2}$. Tymczasem „inna” teoria tej poezji ${ }^{53}$ jest możliwa, także dzięki włączeniu w jej obręb eksperymentów lingwistycznych, którym niejednokrotnie towarzyszy

${ }^{49}$ „Jakie są relacje między poezją lingwistyczną a teorią?” - pytał Skrendo, odpowiadając jednocześnie - „wydaje się bowiem, że poezja lingwistyczna jest w intymny i dwuznaczny sposób powiązana z teoria, powiązana mocniej niż inne rodzaje poezji”; A. Skrendo, Poezja lingwistyczna jako projekt epistemologiczny..., s. 23.

${ }^{50}$ M. Cyranowicz, J. Mueller, J. Radczyńska, dz. cyt., s. 227.

${ }^{51} \mathrm{~W}$ wierszach Bocian - dialogujaccych, niepokornych, buntowniczych i zmagających się z rzeczywistościa - tkwi jednocześnie silna potrzeba jej intelektualnej interpretacji, czego przejawem jest wielokrotnie pojawiająca się w nich „myśl” i czynność „myślenia”, np. w Myśleniu, Myślach petnych ciepła, Widzeniu nieszczęśliwego czy Nadziei. Również teksty Latawiec ujawniają intelektualizm podmiotowego poznania i łączą racjonalność z sensualną wrażliwościa - poetka nieustannie myśli wiersze i myśli świat w wierszach, chcąc „ogarn[aćc] całość: / wszystko zobaczone, dotknięte, pomyślane" (Migot i btysk, B. Latawiec, Gdyby czas byt ziemia, Sopot 2011; zob. też: J. Grądziel-Wójcik, Przymiarki do istnienia..., s. 158). O Miłobędzkiej zaś trafnie pisała Kluba: „Właściwym obiektem zainteresowania jest w tej poezji relacja świat-myśl, a dopiero wtórnie świat-język. [...] myśl wpływa tu na kształt języka, a nie odwrotnie"; A. Kluba, dz. cyt., s. 109.

${ }_{52}$ Określenie Piotra Śliwińskiego, ukute na użytek późnej twórczości Joanny Pollakówny, Julii Hartwig i Adriany Szymańskiej, można uznać za etykietujące poezję kobiet en bloc; zob. P. Śliwiński, dz. cyt., s. 84. Jednocześnie, formułując zadania dla nowej poezji, badacz dopomina się o poezję eksperymentu i „postaw rebelianckich”, sygnowaną nazwiskiem poety-lingwisty Tymoteusza Karpowicza (tamże, s. 51).

${ }^{53} \mathrm{O}$ „innej” teorii poezji na przykładzie twórczości Rafała Wojaczka i Anny Świrszczyńskiej, „której jednym z najważniejszych składników była problematyka ciała i płci”, pisał 
sformułowany program, ujawniający nie tylko poetyckie światopoglądy autorek, ale będący także składnikiem większych projektów o wymiarze egzystencjalnym i tożsamościowym ${ }^{54}$.

Warto zauważyć, iż sąd o zbytniej tradycyjności tej poezji, mimo lingwizujących eksperymentów i metapoetyckich komentarzy, swoistej nieortodoksji w neoawangardowych praktykach, nie musi się odnosić jedynie do twórczości reprezentowanej przez kobiety. Liczne przykłady zebrane w monografii Nauka chodzenia. Teksty programowe późnej awangardy, której autorzy śledzą późnonowoczesną świadomość w metapoetyckich wypowiedziach przedstawicieli polskiej neoawangardy lat sześćdziesiatych i siedemdziesiątych XX wieku (także tych stanowiących korpus formacji lingwistycznej ${ }^{55}$ ), pokazuja, że poezja tego czasu pisana przez mężczyzn w równej mierze stanowi niedokończony projekt awangardy. Interpretacyjne zbliżenia twórczości poszczególnych poetów ujawniaja konceptualizowaną na różne sposoby relatywność czy zachowawczość artystycznych propozycji - postrzeganych w refleksji badawczej jako „anachroniczne”, „zadomowione” czy „tradycjonalistyczne”, potwierdzające tym samym utopijność założeń historycznej awangardy oraz swoista nieczystość jednostkowych realizacji. To pęknięcie wewnątrz metatekstowo obudowanych projektów, łączących dążenie do eksperymentalnej formy z modelem „klasycznie” zorientowanej literatury, wyzwala w efekcie charakterystyczny dla owego czasu „,amalgamat awangardowości i tradycji”" ${ }^{56}$, sprzyjając znaczącym transakcentacjom w definiowaniu pojęcia polskiej wersji neoawangardy. Diagnozę tę odnieść można ogólnie do powojennej twórczości literackiej, bez szczególnego traktowania tej pisanej przez kobiety, której zachowawczość czy retrospektywność jest zwykle w opracowaniach akcentowana. Właściwościa, a być może także wartością polskiej powojennej literatury, determinowanej wszak innymi niż

Andrzej Niewiadomski, zob. tegoż, Światy z jawnych stów i kwiatów ukrytych: o refleksji metapoetyckiej w nowoczesnej poezji polskiej, Lublin 2010, s. 354.

${ }^{54}$ Własna, poetycka, „teorię poezji” wspartą na lingwistycznych chwytach, a zarazem budującą szerszy projekt egzystencjalny, przynosi np. twórczość Urszuli Kozioł; zob. J. Gradziel-Wójcik, „Znikopis” Urszuli Koziot, czyli arspoetyka jednorazowego użytku, „Forum Poetyki”, zima 2017, <http://fp.amu.edu.pl/znikopis-urszuli-koziol-czyli-arspoetyka-jednorazowego-uzytku/> [dostęp: 6.08.2018].

${ }^{55}$ Wśród bohaterów książki znajdziemy m.in. Witolda Wirpszę, Tymoteusza Karpowicza, Krystynę Miłobędzka, Stanisława Dróżdża, Zbigniewa Bieńkowskiego, Edwarda Balcerzana, Mirona Białoszewskiego, a także poetów nowofalowych.

${ }^{56}$ Określenie Kacpra Bartczaka w odniesieniu do poetów nowojorskich; zob. K. Bartczak, Uwagi o awangardowości Johna Ashbery'ego i Franka O'Hary w świetle tradycji Emersonowsko-pragmatystycznej oraz w zestawieniu z poetyka Czestawa Miłosza, [w:] Nauka chodzenia, t. 2: Teksty programowe późnej awangardy, red. W. Browarny, P. Mackiewicz, J. Orska, Kraków 2018. 
na Zachodzie polityczno-społecznymi okolicznościami ${ }^{57}$, jest właśnie owa dekoncentracja obrazu, wewnętrzna niekonsekwencja neoawangardowej formacji - pełnej paradoksów, pęknięć, niespójności widocznych szczególnie w planie zbliżeń tekstowych, a dotyczących tak poezji kobiet, jak i mężczyzn. Co jednak znamienne, choć powojenna neoawangarda czasów PRL-u została pokazana w Nauce chodzenia w całej swej różnorodności i skomplikowaniu, w nowym porządkowaniu „eksperymentalnych zjawisk w powojennej sztuce z punktu widzenia przemian w literaturze" ${ }^{58}$, w założeniu mającym wydobywać to, co dotąd bytowało na marginesie lub, uznawane za quasi-awangardowe, nie mieściło się w „klasycznym” myśleniu o prądzie, zabrakło refleksji nad (nie)obecnością czy marginalizacją neoawangardowych projektów kobiet. Potwierdzeniu podlega zatem werdykt historii literatury, który usuwa poetki poza obszar „nowoczesności”, tłumiąc ich działania awangardowe, metapoetyckie czy eksperymentatorskie $-\mathrm{z}$ jednym zwyczajowo wyjątkiem, jaki w opracowaniach stanowi casus Miłobędzkiej.

Czy zatem, by zacytować Mariannę Bocian, poezji kobiet „jest pisane w pisaniu przegranie"?59. Z jakiegoś bowiem powodu poetki przegrywaja rywalizację o uwagę badaczy. Można się zastanawiać, na ile ten stan rzeczy wynika z mniejszego udziału kobiet w życiu literackim, na ile z poziomu artystycznego ich twórczości, na ile wreszcie z manipulacji, o której wspominał Maliszewski - więcej niż o praktyce literackiej obecne status quo zdaje się mówić o mechanizmach recepcji i polityce budowania kanonu. Gdy przyjrzymy się zarówno poezji poszczególnych autorek, jak i jej krytycznoliterackiemu odbiorowi, okaże się, że także tym docenionym i mianowanym „lingwistkami” nie udaje się trafić do kompendiów, a tym samym zaistnieć w historycznoliterackim obiegu i powszechnej świadomości. Nawet jeśli (nieliczne) tematyczne opracowania poezji lingwistycznej XX wieku przywołuja w egzemplifikacjach nurtu nazwiska piszących kobiet - Wisławy Szymborskiej, Urszuli Kozioł, Ewy Lipskiej, Krystyny Miłobędzkiej czy Marianny

${ }^{57}$ Istotny jest tu wyraźny nacisk okoliczności polityczno-społeczno-ekonomicznych, które determinowały rozwój i rozumienie ruchów neoawangardowych lat sześćdziesiątych i siedemdziesiątych w Polsce - to nasza „lokalna polityczność” zadecydowała przede wszystkim o specyfice i odmienności wobec innych wariantów nurtu rozwijających się w krajach słowiańskich, na zachodzie Europy czy w Stanach Zjednoczonych. Wszelkie paradoksy i niespójności poszczególnych projektów, które opisane zostały w Nauce chodzenia, wynikają tak z lokalnych uwarunkowań „określonej epoki”, jak i różnic rodzimego wariantu awangardy, konfrontowanego tu z wydaniami europejskimi i amerykańskim, ze szczególnym uwzględnieniem kontrkulturowego zaplecza formacji.

${ }^{58}$ J. Orska, Nauka chodzenia..., s. 12.

${ }^{59}$ M. Bocian, Wyznanie konieczne, [w:] tejże, Poezje wybrane, Wrocław 1998, s. 22. 
Bocian $^{60}$. Wciąż potrzebnym działaniem jest zatem swoista „praca u podstaw" - uzupełnianie, także w zakresie lingwizmu, białych plam na mapie poezji XX wieku, powrót na nią autorek niesłusznie zmarginalizowanych lub „pogubionych” w historii literatury. Ma rację Joanna Orska, gdy upomina się o Miłobędzką, która „wraz ze swoim debiutem (Anaglifami z 1960) mogłaby zostać włączona do grona bohaterów Próby porzadkowania doświadczeń Janusza Sławińskiego" ${ }^{61}$. Ten krag w drugiej połowie lat sześćdziesiąych znacząco powiększyłyby wiersze Latawiec, Bocian czy Kozioł, której - jak zauważa Małgorzata Mikołajczak - „,m]etajęzykowa refleksja [...] znajduje [...] wiele punktów wspólnych z poezją lingwistyczną pokolenia ' 56 , zwłaszcza Białoszewskiego i Karpowicza"62.

Szybko się jednak okazuje, że „mechaniczne” włączenie poetek w istniejące historycznoliterackie kategoryzacje i dopasowywanie ich twórczości do przyjętych podziałów i kategorii, nie jest możliwe. Działanie takie prowadzi zwykle albo do marginalizacji i zubożenia analizowanej poezji, która jawi się jako satelicka, mniej ważna i wartościowa, albo do uznania jej za wyjątkową i osobną - w obu przypadkach w domyśle drugorzędną w porównaniu $\mathrm{z}$ „męskimi” wzorcami ${ }^{63}$. Pokazuje to wyraźnie przykład lingwistycznego dorobku Ewy Lipskiej, której - w przeciwieństwie do wymienionych wcześniej autorek - udało się zapisać na kartach podręczników. Jej miejsce okazuje się jednak szczególne - poetka sytuowana jest zwykle na obrzeżach Nowej Fali, kojarzona z omawianym tu nurtem i zarazem odsuwana na jego boczny tor. Dla Stanisława Stabry lingwizm Lipskiej jest „nieco przeintelektualizowany” i zarazem silnie sfunkcjonalizowany - „lingwistyczna gra” czy „stylistyka” służą oddaniu „pesymistycznej, konkretnej, autoironicznej wizji

${ }^{60}$ Anna Świrek omawiała twórczość Lipskiej i Szymborskiej (A. Świrek, W kręu wspótczesnej poezji lingwistycznej, Zielona Góra 1985, s. 147-165), zaś Dariusz Pawelec dostrzegał komponent „lingwistyczny” w poezji Szymborskiej, Kozioł i Lipskiej (D. Pawelec, Między dyskrecja a dyspersja...). Jednakże modelowym przykładem zostaje Miłobędzka, którą przywołuja w opracowaniach tematu Agnieszka Kluba, Piotr Bogalecki, Anna Legeżyńska - u tej ostatniej wspomniana zostaje również Marianna Bocian (zob. A. Kluba, Poetyki lingwistyczne..., P. Bogalecki, Szczęśliwe winy teolingwizmu..., A. Legeżyńska, Od kochanki do psalmistki...). O wiele lepiej rzecz wygląda, jeśli chodzi o autorki debiutujące po roku 1989 - tu w kręgu lingwizmu pozostają Joanna Mueller, Maria Cyranowicz, Katarzyna Hagmajer, Justyna Bargielska, Joanna Roszak, Aneta Kamińska, na różne sposoby podejmujące grę z językiem i w różnym stopniu opisane.

${ }^{61}$ J. Orska, Życie słowa. Składnia wiersza (post)awangardowego, [w:] Przyboś dzisiaj. red. Z. Ożóg, J. Pasterski, M. Rabizo-Birek, Rzeszów 2017, s. 107.

${ }^{62}$ M. Mikołajczak, Podjać przerwany dialog. O poezji Urszuli Koziot, Kraków 2000, s. 125.

${ }^{63}$ Generalnie można mówić o dwóch przeciwstawnych sposobach wprowadzania poetek do podręczników, zwykle ze sobą współistniejących: strategii asymilującej bądź alienującej; więcej na ten temat zob. J. Grądziel-Wójcik, Konstelacje neoawangardy w poezji kobiet... 
indywidualnej egzystencji, zderzonej z Historią w realiach współczesnej cywilizacji” oraz „katastroficznej wizji współczesnej cywilizacji” ${ }^{4}$. Z kolei Stanisław Burkot, przywołując twórczość poetki, nie posługuje się wobec niej kategorią lingwizmu, akcentujacc w zamian jej związki z neoklasycyzmem $^{65}$. Przypomina co prawda wiersz My z 1965 roku jako programowe wystapienie pokolenia i umieszcza jego autorkę „w grupie rówieśniczej”, jednocześnie jednak podkreśla jej odrębność: „kolejne tomiki wykazują nie tylko niezależność od formuł programowych poszczególnych grup, ale także wyjątkową konsekwencję w budowaniu własnego świata poetyckiego. Ewa Lipska od początku należała do najwybitniejszych indywidualności w kręgu współdebiutantów”66. Autorzy poznańskiego podręcznika dostrzegaja u poetki, która „w swoim pokoleniu reprezentowała [...] postawę outsidera”, podobna „,niezgodę na rzeczywistość”, jak u pozostałych członków pokolenia, z tą różnica, że „mniej zajmuje ją socjosfera, bardziej zaś życie wewnętrzne człowieka żyjącego w "peerelu». Natomiast konsekwencje niezgody sa podobne: nieufność wobec świata zastanego i, do pewnego stopnia, nieufność wobec języka" ${ }^{67}$. Lipska jawi się zatem jako lingwistka osobna, bardziej zainteresowana światem niż językiem, przesuwająca akcenty w nowofalowej odsłonie lingwizmu, firmowanej przez Barańczaka czy Krynickiego. Tę alienacyjną tendencję potwierdzają obserwacje Maliszewskiego, który przeglądając podręczniki, antologie i inne kompendia - pokazuje mechanizm „wyrzucania” piszących kobiet z historycznoliterackich zapisów, „usuwania [ich] w cień” czy „ubywania z pokolenia”, podkreślając nieprzystawalność wytwarzanych przez nie ,innych” kategorii estetycznych do myślenia męskocentrycznego. Szczególną uwagę poświęca Ewie Lipskiej, której nazwisko stopniowo zaczęło znikać z opracowań podręcznikowych, mimo silnie zaznaczonej przynależności do pokolenia początku lat siedemdziesiątych:

Zbigniew Jarosiński w książce Literatura lat 1945-1975 w rozdziale pt. Pokolenie '68 pomija to nazwisko jako niemieszczące się w opisie „formacji mającej jasno wytyczony program artystyczny"68. Domyślamy się, że na tle jasno wytyczonego programu odrębny czy prywatny program Lipskiej jawił się jako „osobliwość”. Nato-

${ }^{64}$ S. Stabro, Literatura polska: 1944-2000 w zarysie, Kraków 2005, s. 59, 175.

${ }^{65}$ S. Burkot, Literatura polska w latach 1939-1989..., s. 214-215. Autor wspomina w swojej syntezie również o Urszuli Kozioł, która początkowo zwracała się ku ruchom awangardowym; tamże, s. 102.

66 Tamże, s. 214-215.

${ }^{67}$ A. Legeżyńska, P. Śliwiński, Poezja polska po 1968 roku, Warszawa 2000, s. 50-51. Poetka jest „kojarzona” z pokoleniem ‘68 także w innej poznańskiej syntezie (B. Kaniewska, A. Legeżyńska, P. Śliwiński, Literatura polska XX wieku, Poznań 2005, s. 32), najsilniej zaś w kręgu Nowej Fali umocowuje ją Anna Nasiłowska, rozpoczynając od niej omawianie twórczości tego nurtu (A. Nasiłowska, Literatura okresu przejściowego 1975-1996, Warszawa 2007, s. 105).

${ }^{68}$ Z. Jarosiński, Literatura lat 1945-1975, Warszawa 1996, s. 121. 
miast czymś takim nie była ówczesna twórczość wymienionych panów - Stanisława Barańczaka, Juliana Kornhausera, Adama Zagajewskiego, Ryszarda Krynickiego, Krzysztofa Karaska i Jacka Bierezina. W tym ujęciu Nowa Fala wydaje się być formacją wybitnie męska, liryczna kobiecość w granicach jej realnego znaczenia właściwie nie wystapiła ${ }^{69}$.

„Liryczna kobiecość” w połączeniu z lingwistycznym komponentem raz jeszcze okazuje się „trudna” do zaakceptowania, nie przystając do obowiązującego rozumienia nurtu. Mimo wszystko jednak Lipska należy do nielicznych poetek, które - jak piszą autorki Solistek - „mają twarz” w historii dwudziestowiecznej polskiej poezji, co, rzecz jasna, „, żadnym stopniu nie oddaj[e] potencjału literackiego kobiet"70. Wyraźny portret wśród lingwistek zyskała jeszcze tylko Krystyna Miłobędzka.

Powyższy rekonesans uświadamia, jak trudno zaistnieć poetkom w „męskim” świecie awangardy, metarefleksji i lingwizmu. Niemożliwe jest oczywiście napisanie od nowa historii polskiej poezji, można jednak - i trzeba - dokonywać w jej ramach lokalnych przewrotów, obalać skostniałe konstrukcje, (d)opisując także poszczególne praktyki lingwistyczne kobiet. Warto przypominać przeoczone lub zapoznane autorki, a tym samym uzupełniać i komplikować obowiązującą narrację historycznoliteracka, która nieuchronnie ujawni swój ograniczający charakter. W gruncie rzeczy przecież chodzi wciąż o to samo - dalsze „porządkowanie doświadczeń”, metodologicznie nieortodoksyjne i obejmujacce spojrzeniem także poetyckie dokonania kobiet. Nie tyle bowiem nie istnieje lingwistyczna poezja kobiet, ile nie mieści się ona w obowiązujących definicjach tej orientacji. Uwzględnienie twórczości poetek, zwłaszcza lat sześćdziesiątych i siedemdziesiątych, poszerzyłoby czy skomplikowało wytyczone swego czasu przez Sławińskiego pole możliwości, sprawdzające się jedynie w „męskiej” linii. Jak bowiem pisał Andrzej Skrendo, ,[k]łopot teorii lingwizmu jest kłopotem teoretycznym"71 (z czego wynika także kłopot historycznoliteracki) i takie właśnie „podejrzewanie” poezji lingwistycznej, stopniowy proces „rozburzania” (by powiedzieć Przybosiem ${ }^{72}$ ) „monolitycznej formuły «lingwistyczności»” "73, jej komplikowania i reinterpretowania trwa już od lat. Praktyki lingwistyczne kobiet, obecnie zwłaszcza działalność Joanny Mueller czy Justyny Bargielskiej, wspomagają ten proces dekonstrukcji, domagając się osobnego miejsca na ich dokładne omówienie.

\footnotetext{
${ }^{69}$ K. Maliszewski, Przetomy i pokolenia bez kobiet?..., s. 45.

${ }^{70}$ M. Cyranowicz, J. Mueller, J. Radczyńska, Solistki bez chóru..., s. 226.

${ }^{71}$ A. Skrendo, Poezja lingwistyczna jako projekt epistemologiczny..., s. 33.

${ }^{72}$ „Jakże ściany rozburzę, jak burzy nadążę!”, czytamy w wierszu Juliana Przybosia $Z$ okna brzoza (z tomu W gtab las); J. Przyboś, Utwory poetyckie, oprac. R. Skręt, t. 1, Kra-
} ków 1984, s. 82.

${ }^{73}$ A. Kluba, Poetyki lingwistyczne..., s. 101. 


\section{BIBLIOGRAFIA}

Balbus S., Z dziennika lektur poetyckich, „Życie Literackie” 1971, nr 1.

Barańczak S., Nieufni i zadufani. Romantyzm i klasycyzm w młodej poezji lat 60., Wrocław 1971.

Bartczak K., Uwagi o awangardowości Johna Ashbery'ego i Franka O'Hary w świetle tradycji Emersonowsko-pragmatystycznej oraz w zestawieniu z poetyka Czesława Miłosza, [w:] Nauka chodzenia. T. 2. Teksty programowe późnej awangardy, red. W. Browarny, P. Mackiewicz, J. Orska, Kraków 2018.

Błoński J., Diagnozy i prognozy, [w:] J. Błoński, Odmarsz, Kraków 1978.

Bocian M., Bez manifestu, [w:] Konkrety [katalog wystawy Marianny Bocian], Wrocław, 1971.

Bocian M., Przestrzeń w poezji konkretnej. Ogólnopolskie sympozjum nt. poezji konkretnej, Bydgoszcz 20-21 października 1979 r., Bydgoszcz 1979.

Bogalecki P., Niedorozmowy. Kategoria niezrozumiałości w poezji Krystyny Miłobędzkiej, Warszawa 2011.

Bogalecki P., Szczéśliwe winy teolingwizmu. Polska poezja po roku 1968 w perspektywie postsekularnej, Kraków 2016.

Burkot S., Literatura polska w latach 1939-1989, Warszawa 1993.

Cieślak-Sokołowski T., Moment lingwistyczny. O wczesnym pisarstwie Ryszarda Krynickiego i Stanisława Barańczaka, Kraków 2011.

Cieślak-Sokołowski T., Przy słowie, „Dekada Literacka” 2008, nr II-III.

Cyranowicz M., [w:] Gada!Zabić. Pa]n[tologia neolingwizmu, nawigacja: M. Cyranowicz, P. Kozioł, Warszawa 2005.

Cyranowicz, Mueller J., Radczyńska J., Solistki bez chóru. Pożyteczne refleksje, [w:] Solistki. Antologia poezji kobiet (1989-2009), red. M. Cyranowicz, J. Mueller, J. Radczyńska, rysunki P. Dwurnik, M. Ignerska, Warszawa 2009.

Dawidek-Gryglicka M., Ścieżki języka wedtug Marianny Bocian, [w:] M. Dawidek-Gryglicka, Historia tekstu wizualnego. Polska po 1967 roku, Kraków-Wrocław 2012.

Dembińska-Pawelec J., Arachne z ulotnq niciq. Sygnatura kobieca w późnej poezji Bogusławy Latawiec, „Poznańskie Studia Polonistyczne. Seria Literacka” 2018, nr 32.

Drzewucki J., Język w języku, „Rzeczpospolita”, 31 VII 1999.

Grajewski W., W środku myśli, „Poezja” 1970, nr 12.

Grądziel-Wójcik J., Konstelacje neoawangardy w poezji kobiet na przykładzie twórczości Julii Fiedorczuk, „Zagadnienia Rodzajów Literackich” 2018, z. 2.

Grądziel-Wójcik J., Przymiarki do istnienia. Watki i tematy poezji kobiet XX i XXI wieku, Poznań 2016.

Grądziel-Wójcik J. „Znikopis” Urszuli Koziot, czyli arspoetyka jednorazowego użytku, „Forum Poetyki”, zima 2017, <http://fp.amu.edu.pl/znikopis-urszuli-koziol-czyli-arspoetyka-jednorazowego-uzytku/> [dostęp: 6.08.2018].

Hoffmann K., Jaworski M., Poezja polska po roku 1989, [w:] Przechadzki po polskiej literaturze najnowszej, red. J. Grądziel-Wójcik, J. Jastrzębska, Z. Kopeć, Poznań 2014.

Hull L., Obok kanonu. Poezja kobiet w przestrzeni literatury po 1945 roku, „Prace Literaturoznawcze" 2013, nr 1.

Iwasiów I., Galant A., Wstęp, [w:] Pisarstwo kobiet pomiędzy dwoma dwudziestoleciami, red. I. Iwasiów, A. Galant, Kraków 2011. 
Jarosiński Z., Literatura lat 1945-1975, Warszawa 1996.

Kaniewska B., Legeżyńska A., Śliwiński P., Literatura polska XX wieku, Poznań 2005. Karpowicz T., Dziennik Zwiazkowy (Polish Daily News), Chicago, 15-17.11.1991.

Klejnocki J., Tajemnica, „Polityka” 2008, nr 2643.

Kluba A., Poetyki lingwistyczne, „Przestrzenie Teorii” 2005, nr 5.

Kraskowska E., Piórem niewieścim. Z problemów prozy kobiecej dwudziestolecia międzywojennego, Poznań 1999.

Krynicki R., Czy istnieje już poezja lingwistyczna?, „Poezja” 1971, nr 12.

Legeżyńska A., Od kochanki do psalmistki... Sylwetki, tematy i konwencje liryki kobiecej, Poznań 2009.

Legeżyńska A., Śliwiński P., Poezja polska po 1968 roku. Warszawa 2000.

Lisowski K., „O czasie po czasie”, „Nowe Książki” 2015, nr 5, <http://www.wforma.eu/-oczasie-po-czasie-nowe-ksiazki-12-2015.html> [dostęp: 6.08.2018].

Łuszczykiewicz P., Wiersze, sny, obrazy Bogusławy Latawiec, [w:] J. Grądziel-Wójcik, P. Łuszczykiewicz, Bogusława Latawiec. Portret podwojony, Kraków 2016.

Maliszewski K., Przetomy i pokolenia bez kobiet?, [w:] Formy (nie)obecności. Szkice o wspótczesnej poezji kobiet, red. J. Grądziel-Wójcik, E. Sołtys-Lewandowska, A. Kwiatkowska, Kraków 2018.

Matuszewski R., Woda, palce, litery, „Życie Literackie” 1965, nr 31.

Mikołajczak M., Podjać przerwany dialog. O poezji Urszuli Kozioł, Kraków 2000.

Nasiłowska A., Literatura okresu przejściowego 1975-1996, Warszawa 2007.

Niewiadomski A., Światy z jawnych słów i kwiatów ukrytych: o refleksji metapoetyckiej $w$ nowoczesnej poezji polskiej, Lublin 2010.

Nyczek T., Wieża Babel, albo w pętli słowa, „Konfrontacje Literackie” 1972 [suplement]. Orska J., Nauka chodzenia. O programowych wypowiedziach późnej awangardy, [w:] Nauka chodzenia, t. 1. Teksty programowe późnej awangardy, red. W. Browarny, P. Mackiewicz, J. Orska, Kraków 2018.

Orska J., Życie słowa składnia wiersza (post)awangardowego, [w:] Przyboś dzisiaj, red. Z. Ożóg, J. Pasterski, M. Rabizo-Birek, Rzeszów 2017.

Pawelec D., Między dyskrecja a dyspersja. Oblicza końca poezji lingwistycznej, „Poznańskie Studia Polonistyczne. Seria Literacka” 2006, z. XIII.

Powiedzieć to inaczej. Polska liryka nowoczesna. Antologia. Autorzy wyboru J. Borowczyk, M. Larek, Poznań 2011.

PRL - świat (nie)przedstawiony, red. A. Czyżak, J. Galant, M. Jaworski, Poznań 2010. Przyboś J., Utwory poetyckie, oprac. R. Skręt, t. 1, Kraków 1984.

Ritz G., Kanon i historia literatury. Widziane z zewnatrz, [w:] Kanon i obrzeża, red. I. Iwasiów, T. Czerska, Kraków 2005.

Sienkiewicz B., (Neo)lingwizm - dokończony projekt awangardy, [w:] B. Sienkiewicz, Poznawanie i nazywanie. Refleksja cywilizacyjna i epistemologiczna w polskiej poezji modernistycznej, Kraków 2007.

Skrendo A., Poezja lingwistyczna jako projekt epistemologiczny. Zerwanie, ustanowienie, zawieszenie, „Poznańskie Studia Polonistyczne. Seria Literacka” 2006, z. XIII.

Sławiński J., Próba porzadkowania doświadczeń, [w:] J. Sławiński, Prace wybrane, t. V. Przypadki poezji, red. W. Bolecki, Kraków 2001.

Stabro S., Literatura polska: 1944-2000 w zarysie, Kraków 2005. 
Szaruga L., Rozptywajace się zdanie, „Nowe Książki” 1995, nr 10.

Śliwiński P., Przygody z wolnościq. Uwagi o poezji wspótczesnej, Kraków 2002.

Świerkosz M., Historia literatury kobiet - niedokończony projekt, „Wielogłos” 2011, nr 2.

Świrek A., W kręgu wspótczesnej poezji lingwistycznej, Zielona Góra 1985.

Wesołowski J., Konkretna poezja. Materiały do „Stownika rodzajów literackich”, „Zagadnienia Rodzajów Literackich” 1974, R. XVII, z. 2.

Witan J., Niepokój zamkniętych słów, „Odra” 1966, nr 9.

Woroszylski W., Dwugłos o „Nigdy całości”, „Arkusz” 1995, nr 4.

Zawada A., Od krzyku do milczenia, „Poezja” 1974, nr 1 (98). 